Ж.В. Котов

\title{
ВОЗМОЖНОСТЬ ФИЛОСОФИИ СОУЧАСТИЯ
}

\section{1.Актуальность темы}

Данная статья носит проблемный, постановочный характер это как бы приглашение к дискуссии, приглашение поразмыслить и каждому в отдельности и всем вместе над тем, как возможна философия в качестве философии соучастия?

1.1. Дискуссионность проблемы задается как многоплановостью и известной неопределенностью того реального феномена, который находит свое идеальное отражение в понятии философии соучастия, так и необходимостью сочетания софийного и эпистемного способов философствования (феноменологически описательного и абстрактно-логического подходов). Обсуждение данной темы открывает возможность одновременного осмысления аспектов и личностного, и общественного бытия. В той мере, в какой тебе удастся понять и выразить подлинно человеческое начало в себе, в той же мере ты фактически выразишь и общечеловеческое. "Индивидуальная и родовая жизнь человека, - замечает молодой Маркс, - не являются чем-то различным, хотя по необходимости способ существования индивидуальной жизни бывает либо более особенным, либо более всеобщим проявлением родовой жизни" (10. - С.119). К примеру, у М.Мамардашвили, - в книге "Необходимость себя", - представлены его размышления над собственными личностными проблемами. В своих попытках, говоря словами Э.Фромма, найти наиболее адекватные собственные ответы на "проблему человеческого существования", опираясь на современную философскую культуру, он фактически и решает проблему "собирания себя". Но поскольку в размышлениях Мамардашвили наличествует исключительная глубина и основательность, постольку эти размышления оказываются общезначимы и интересны.

Если философствующий индивид, размышляя над личностно значимыми проблемами, сумел их достаточно глубоко осмыслить, то это предполагает, что он натолкнулся на проблему об- 
щезначимую, так или иначе решаемую многими. В этом случае перед ним открывается новая возможность и необходимость "не выдумывать связи из головы", а понять то действительное движение, которое происходит перед нашими глазами и стать сознательным выразителем этого. В то же время важно учитывать, что философия совмещает в себе потенциал не только науки, но и искусства, и новые мировоззренческие идеи и подходы формируются первоначально в философии как ценностной форме общественного сознания.

В порядке дискуссии желательно поразмыслить над следующими вопросами. Что можно понимать под философией соучастия? Как возможна (если возможна) философия соучастия, где, когда, для кого и при каких условиях? Не является ли предложенная к обсуждению проблема псевдопроблемой?

1.2. В свою очередь, дискуссия оказывается плодотворной только в том случае, если, с одной стороны, речь идет об актуальной жизненной проблеме, а, с другой, предлагается гипотеза, ориентированная на включение в ее теоретическое осмысление и разрешение. В качестве актуальной жизненной проблемы, требующей своего разрешения, может выступать, в частности, ситуация нравственного кризиса, охватившего не только наше, но и все мировое сообщество. В качестве теоретической может выступать проблема разработки такой философии, которая открывала бы возможность выработки культуры мировоззренческой рефлексии, позволяющей людям принять на себя ответственность за реализацию смысла своей жизни. "Нравственный кризис, о котором заговорили во весь голос совсем недавно, отмечает Д.А.Леонтьев в своей вступительной статье к работе В. Франкла "Человек в поисках смысла", - это не что иное, как ощущение огромным числом людей бессмысленности той жизни, которую им приходится вести, нередко без возможности найти в ней позитивный смысл из-за разрушения старых ценностей и традиций, дискредитации "новых" и отсутствия культуры мировоззренческой рефлексии, позволяющей прийти к уникальному смыслу своим, неповторимым путем. Скольких бы трагедий могло бы не быть, если бы люди не были ограничены в своих возможностях - и внешних, объективных, и внутренних, 
личностных, - построить свою жизнь разумно и ответственно, принять на себя ответственность за реализацию смысла своей жизни и воплотить этот смысл в жизнь" (13. - С.5-6).

Таким образом, необходима культура мировоззренческой рефлексии, позволяющая индивиду в условиях духовного кризиса, связанного с потерей смысложизненных ориентиров, приходить к уникальному смыслу своим, неповторимым путем. Справедливо ли предположение, что, в первую очередь, индивиды, профессионально занимающиеся философией, призваны первоначально теоретически осмыслить, а затем и на опыте своей жизни показать возможность приобщиться к культуре мировоззренческой рефлексии, позволяющей приходить к уникальному смыслу своим неповторимым путем, строить свою жизнь разумно и ответственно, принимать на себя ответственность за реализацию смысла своей жизни и воплощения этого смысла в жизнь? Если индивид, профессионально занимающийся философией в мировоззренческих ее аспектах, по своей сути призван быть ориентирован на представленность философии в ее соучастии человеку как родовому существу, то может ли (и должен ли) он в принципе осваивать и развивать философию в ее представленности его личностному бытию?

Ситуация, когда философствующий субъект учит уму разуму всех, но не может помочь самому себе в осмыслении мира своей повседневности, в придании большей полноты своему индивидуальному бытию через осмысление проблемы своего человеческого существования с позиций его направленности на "продуктивную ориентацию" (Э.Фромм), свидетельствует о его фактической отчужденности от самого процесса философствования. Философию в содержательном ее аспекте мы рассматриваем в данном случае как "поиск оснований человеческого бытия" (Г.А.Антипов). Поиск оснований человеческого бытия может иметь место как на уровне обыденного сознания, так и в пределах какой-то одной культурной сферы - искусства, науки, религии и т.д. Но строго последовательно и обстоятельно философствование может проходить только в рамках профессиональной философской деятельности. Формальный аспект философствования (речь идет о содержательной форме) предпола- 
гает, как замечает В.С. Библер, что философствующий индивид получает возможность, во-первых, "преобразовывать свой индивидуальный ум в разум по особенному всеобщий", включившись в поиск оснований человеческого бытия, во-вторых, актуализировать "одну из бесконечных возможностей бесконечновсеобщего бытийного смысла", "вступая в общение с иными, столь же индивидуально-всеобщими разумами" (1. - С.170).

Включившись в профессиональное занятие философией, я также через определенный промежуток времени обнаружил, что часто оказываюсь в ситуации отчуждения и от себя лично, и от своей собственной профессиональной деятельности. Возникла личностная потребность в теоретической рефлексии над данной проблемой. И если верна схема - "отчуждение - освоение - гармония" (Ф.И.Прокофьев), - то возникает вопрос о роли философии в решении проблемы преодоления отчуждения.

1.3. В качестве философии, ориентированной на помощь в выработке необходимой культуры мировоззренческой рефлексии, в первую очередь, для тех, кто профессионально занимается философией, как раз и может выступать философия соучастия. Философия соучастия необходима как средство преодоления отчуждения через "освоение" посредством рефлексии над наличной ситуацией с последующим выходом в ситуацию гармонии духовного бытия. Но многие ли из тех, кто профессионально занимаются философией, способны включиться в процесс выработки для себя лично (а тем самым и других людей) мировоззренческих ориентиров или хотя бы в процесс осмысление причины своей неготовности к этому? "Величие человека, - по мнению М. Метерлинка, - измеряется величием тайн, которые его занимают или перед которыми он останавливается" (см.11. - С.10). Многие ли готовы заинтересоваться тайной философии соучастия? Мы ставим вопросы не столько для осмысления данной проблематики применительно к "генералам от философии", сколько применительно к "рядовым от философии".

Вопрос о том, для кого может быть интересна проблематика философии соучастия, имеет три варианта значимости. Ибо у одних хоть изредка бывали времена, когда философия выступала соучастною их личностным проблемам, для других она 
никогда не бывала соучастною, а для третьих она, условно говоря, соучастна всегда. Представляется, что именно первые оказываются в наибольшей мере готовы к философской рефлексии над данной проблемой, заинтересованы в ней. Неготовность к размышлению над данной проблемой может обнаруживаться либо в тех случаях, когда индивид находится на уровне природной нравственности и не перешел еще в ситуацию необходимости самостоятельного движения в освоении культуры, либо при тех обстоятельствах, когда он не воспринимает собственное бытие как проблему и не испытывает потребность выхода из ситуации "тягомотины повседневной жизни" посредством восприятия особой "метафизической реальности". Можно также предположить, что готовность к размышлению над данной проблемой определяется выходом индивида на экзистенциальный уровень бытия, а тем более на уровень "работы души".

Философия соучастия, в первую очередь, ориентирована на тех, кто профессионально занимается философией, а также на представителей (носителей) "свободной интеллигентности". Индивиду, профессионально занимающемуся философией, философия соучастия необходима:

1) для того, чтобы с позиций философской культуры он был готов в кризисных ситуациях своего повседневно-практического освоения мира философски грамотно, корректно и эффективно "выходить из пике", вырываться из ситуации "потока", из ситуации "дурной бесконечности" в ситуацию "умного бытия";

2) для того, чтобы в преподавании философии (или написании книг) он имел бы возможность и потребность делиться опытом "собирания себя";

3) для того, чтобы он был готов к творческому общению и с собой, и с другими через посредство подлинных мыслителей.

\section{2. Понятие философии соучастия}

Мы вводим понятие "философия соучастия" в некотором роде как "рабочее понятие", призванное охватить некое поле осмысления, так же как, в частности, В.Франкл, решая подобную 
задачу для себя, вводит понятие "философия ответственности", а Г.Парсонс - "философия удивления".

2.1. Общие контуры этого нового поля осмысления очерчивает проблема преодоления отчуждения от культуры как меры человеческого в человеке, в особенности, проблема преодоления отчуждения индивида, профессионально занимающегося философией, от своей собственной деятельности, от ее продукта, от других людей и от самого себя. Под философией соучастия мы понимаем одновременно и определенный этап в развитии философии, и определенный аспект философской культуры, открывающий возможность отдельному индивиду встать на путь познания самого себя, на путь осознанного отношения к проблеме своего личностного существования, своего предназначения в этом мире. Индивид, погружающийся в духовное пространство философской культуры, вправе ожидать, что философия будет, так сказать, со-чувствовать, со-переживать его проблемам, будет со-участна их осмыслению и разрешению. Но чему, может быть простому самовыражению? Индивиду нужно соучастие в ориентации на продуктивную деятельность и на осуществление смыслов, на то, чтобы помочь ему оставаться человеком даже в самых бесчеловечных обстоятельствах.

Понятие "соучастие" используется, в частности, М.Бубером, размышляющим над проблемой "Я-Ты". "Личность сознает свое со-участие как со-бытие и тем самым как сущую в бытии. Довлеющее себя особенное сознает себя самое как Ты-и-не-иначесуществующее. Личность говорит: "Я есмь", довлеющее себе особенное говорит: "Я такое". "Познай самого себя" означает для личности "познай себя как сущее в бытии", для довлеющего себя особенного - "познай свое определенное бытие". Когда довлеющее себя особенное отделяет себя от других, оно отделяется от бытия" (2. - С.52).

Мы же предлагаем понятие "философия соучастия", вкладывая в него свой, особый смысл. Поскольку данное понятие вводится в таком контексте впервые, встает задача обосновать необходимость введения именно нового понятия, попытаться раскрыть ту особую духовную сферу, которая охватывается понятием "философия соучастия". Это откроет для нас возмож- 
ность войти в рассмотрение практического и теоретического аспектов философии соучастия как проблемы, требующей теоретического осмысления.

2.2. Понятие философии соучастия призвано дополнить и развить понятие индивидной философии. Современная философия, как отмечает Г.Горак, не может уже выступать только как антропологическая философия, рассматривающая проблему человека вообще, ибо нужна философия, учитывающая тот факт, что понятие "человек" есть обобщенное обозначение индивидов, что познает, переживает и проживает свое бытие в этом мире именно конкретный индивид. Философия индивидности обращает внимание на тот факт, что индивид выступает как уникальная пространственно-временная реальность, как уникальная точка, образуемая взаимодействием социального и космически-природного пространства.

Философия при этом как раз и рассматривается как обобщенный опыт человечества в овладении им социального и природно-духовного пространства. Но ведь как нет человека вообще, так и нет индивида вообще. И если философия обобщает опыт освоения социальной и природно-космической реальности, а индивид сам представляет собой особое и уникальное проявление и воплощение этой реальности, то для него как раз и нужна философия и как культура личностной философской рефлексии, и как особая культура жизни, открывающая перспективу не философствовать только, а "жить в философии" (Г.Сковорода).

Возможность такого ракурса в освоении и использовании философской культуры нам показывает М.Мамардашвили. В бытии человека в этом мире он различает возможность его пребывания, как в "потоке", так и в ситуации "умного бытия". Пребывание "в потоке" захватывает человека логикой "дурной бесконечности", логикой существования, сплетенной из мгновений, уходящих в никуда, ибо при этом человеку диктуются действия "естественные" для него главным образом как для природного существа. "Умное бытие" - это те мгновения нашей жизни, которые, раз состоявшись, остаются вечно. "Умное бытие" пребывает рядом с нами, но его нужно открыть, его нужно прочувствовать, в него нужно войти усилием ума и воли. 
В те периоды, когда перед индивидом открывается шанс перепрыгнуть из ситуации "дурной бесконечности" в ситуацию "умного бытия", он получает возможность вхождения в измененные состояния сознания через посредство особого рода рассуждений, которые и являют собой, по мнению М.Мамардашвили, собственно философствование ("реальная философия"). Наличие же профессиональной философской культуры как раз и является условием для того, чтобы оказалось возможным наиболее эффективное структурирование нового, более высокого уровня духовности.

Философия призвана выступать в качестве синтетической формы и знания, и переживания бытия, позволяющей одновременно синтезировать в единую органическую целостность знания, связанные как с внешним миром, так и нашим внутренним опытом, взятые как в их самостоятельности, так и с рассмотрением внешнего и внутреннего опыта как двух сторон одной и той же целостности. "Прежде всего, хочется предложить модель, обладающую большой объяснительной силой, - пишет В.Налимов. - Мы уже устали от локальных моделей, довлеющих над современным научным мировоззрением. Хочется вырваться на простор и с каких-то единых позиций увидеть то, что нам дано увидеть. Увидеть хочется, прежде всего, человека в его погруженности в этот мир - найти его внутреннюю сопричастность смыслам этого мира, данным нам в процессе их творческого самораскрытия" (11. - С.18).

Философия соучастия предполагает такой синтез знаний - и обыденных, и научных, и религиозных, и эзотерических, и философских, - такую культуру эмоционального восприятия и переживания бытия, когда философия действительно может выступать в качестве особого духовного пространства, входя в которое каждый индивид в принципе получает возможность самостоятельно вступать на путь познания, на путь нахождения себя в этом мире, подключается к такому решению проблемы поиска смысложизненных ориентиров, проблемы личностного спасения, когда "спасая себя, спасаешь других, а, спасая других, спасаешь себя". При этом, не отбрасываются возможности философии как в научном познании мира, так и в поисках опти- 
мальных путей преобразования общественной жизни. В определенной мере философия соучастия это как бы тот желательный вариант многоплановой философской культуры, с различными аспектами которой и мог бы и хотел бы взаимодействовать каждый из нас при всем нашем личностном своеобразии и различии.

2.3. Выйти на уровень постижения философии в качестве философии соучастия сумел, в частности, Л.Н.Толстой. Смерть любимого брата Николеньки, наложившаяся на сложные ситуации духовного развития Л.Толстого, поставила его на грань самоубийства, связанного с потерей смысложизненных ориентиров (см. "Исповедь"). И только обращение к философии спасло его, позволило прийти к уникальному смыслу своей жизни собственным, неповторимым путем. Для Л.Толстого философия в личностном плане обнаружила себя как знание, дающее наилучшие возможные ответы о смысле человеческой жизни и смерти. Одновременно он предложил человечеству свой вариант идеи "нравственного самоусовершенствования" в рамках целостного религиозно-этического учения, не потерявшего своей актуальности и в наше время.

Во фронтовом блокноте Э.В.Ильенкова, одного из самых глубоких и ярких представителей философии марксизма в Советском Союзе, сохранилась следующая запись: "Современный человек, как человек, не хорош тем, что внутри себя не имеет того внутреннего устремления, окрашенного радужным светом поэзии, которое раньше называлось Богом... У меня все растет и крепнет убеждение, что нам очень и очень необходим Бог... Именно такой как у Льва Николаевича... Для нас сейчас этот вопрос встал несколько иначе. Идею абстрактную, философскую, мы приняли и не сомневаемся в ее справедливости. Но этическая сторона этой идеи, религиозная, как называет ее Л.Н., нами не воспринята, ее по сути дела нет..." (6. - С.9-10)

Философия может быть соучастна обычному индивиду в тех случаях, когда жизненная необходимость обращения к проблемам "реальной философии" получает свою поддержку у конкретных мыслителей, решавших до этого подобные проблемы "для себя" и сумевших поставить "остро сформулированные вопросы", позволяющие обнаруживать незнание оппонентов, по- 
могающее погружать их сознание в семантическое поле, возбужденное "предельными вопросами бытия". Одни могут, к примеру, обратиться к гуманистическому психоанализу Э.Фромма или логотерапии В.Франкла, другие к философским искания М.Мамардашвили. Весьма плодотворным при этом может оказаться, с нашей точки зрения, знакомство с работами В.В.Налимова и Г.И.Горак.

\section{3.Теоретическая проблематика философии соучастия}

Теоретический аспект философии соучастия может быть представлен, в частности, рассмотрением трех проблем. Вопервых, собственной логики развития философии, открывающей новые возможности для обнаружения философии в качестве философии соучастия. Во-вторых, степени готовности самого общества к тому, чтобы и философия развивалась и индивиды, желающие и готовые подключиться к ее освоению, имели такую возможность. В третьих, необходимого уровня личностного развития индивидов, при котором философская культура не навязывается, но без нее нельзя просто жить, ибо, как верно было замечено, "учитель придет только тогда, когда к этому будет готов ученик".

3.1. Необходимо учитывать и тот факт, что как всякому развивающемуся явлению, философии присуща определенная цикличность, включающая в себя как малые круги, связанные с последовательностью перехода через различные этапы саморазвития - "в себе", "для себя" и "для других", так и большой круг, обусловленный последовательной сменой самих ведущих парадигм философствования - объективистской, деятельностной и коммуникативной. Именно коммуникативная парадигма, призванная утвердиться в наше время в качестве ведущей, как раз и открывает наибольшие возможности для массового приобщения к философии.

Философия соучастия призвана синтезировать, включить в себя "в снятом виде" все многообразие ликов философии, проявившихся, обнаруживших себя в предшествующие периоды ее исторического развития, а сегодня последовательно реали- 
зуемых в относительно отдельных и самостоятельных философских проявлениях и направлениях и как жизненная мудрость, и как наука о принципах, и как учение об абсолюте, и как учение о самопознании человеческого духа.

Философия как размышление о предельных основаниях человеческого бытия начинает появляться (и возрождаться) с того момента, когда ускорение темпов общественного развития и достижение определенного многообразия общественной жизни приводит к тому, что переходы в новые состояния общественного бытия уже не успевают быть отражены на уровне коллективной психологии того или иного сообщества. Возникает необходимость того, чтобы отдельные, выдающиеся индивиды, "вбирая в себя всю боль своего времени" и, вступая на путь самопознания, на путь переосмысления предельных оснований бытия, предлагали варианты решения кризисных проблем. Э.В.Ильенков в статье: "Что же такое личность?" - дает образную характеристику подобного типа личностей, имея в виду, в частности, Платона. Спинозу, Толстого. "Это те личности, которых ни с кем другим не спутаешь, в которых сконцентрировано как в фокусе социально значимое дело их жизни, ломающей косные штампы, с которыми другие люди свыклись, несмотря на то, что эти штампы уже устарели, стали тесны для новых, исподволь созревающих форм отношений человека к человеку" (6. - C.412).

Философия и начинает, и завершает очередные циклы своего развития как жизненная мудрость, обретаемая в процессе подхода к решению сформулированных выше проблем. Философия как жизненная мудрость это то начало, которое обнаруживает свою полноту в моменты завершения относительно самостоятельных циклов развития философии. В свою очередь, с позиций жизненной мудрости открывается возможность постижения логики жизни средствами как интуиции, так и разума. Но осознает философия себя в качестве особой сферы духовной жизни первоначально как наука о принципах, как учение об абсолюте (вне зависимости, выступает ли в качестве такого абсолюта идеальная или материальная субстанция). 
Так, древнегреческая философия начинается как учение о Природе (досократики) и на этом пути фактически встает и решается затем уже в течение столетий развития философской (a затем и научной) мысли задача постижения логики жизни (в ее природных, социальных и духовных проявлениях) средствами разума на уровне общественного сознания в целом, хотя философия предполагает и интуицию. Решение же задачи постижения жизненной мудрости исключительно средствами интуиции и прозрения для общественного сознания в целом остается при этом прерогативой религии, мистики и эзотерических учений. На втором этапе центральной для философской мысли оказывается проблема человека (софисты и Сократ), а также проблема теоретического осмысления противоречий общественной жизни (Платон, Аристотель). Третий, завершающий виток в развитии очередного цикла философской культуры представлен различными вариантами в зависимости от сложившейся исторической ситуации либо закрывающей перспективы прогрессивных общественных преобразований, - a, следовательно, и суживающий возможности для человека быть человеком, либо, напротив, открывающей эти возможности.

Что касается философии античности, то на завершающих этапах своего развития она ориентирована главным образом на решение проблемы как "жить мудро", как оставаться человеком в условиях распада общественных связей и потери идеалов. Стоики и киники размышляли над тем, как остаться человеком и в тех условиях, когда ты беден, и даже тогда, когда общество поставило тебя в ситуацию раба. Эпикурейцы решали ту же проблему, но для тех случаев, когда человек проходит испытание богатством.

Цикличность собственно развития философского знания может быть также представлена тремя этапами. Для первого этапа характерно наличие множества конкурирующих между собой в объяснении мира учений. На втором этапе преобладает процесс синтезирования всех предшествующих достижений в господствующих философских направлениях (фактически здесь осмысливаются те программы познания бытия и развитии общества, которые затем реализуются в течение последующих сто- 
летий). Все это как раз и подготавливает третий этап, этап "обмирщения философии", когда "философия становится мирской", а "мир становится философским". Само "обмирщение" философии, как ее вхождение в жизнь через включенность в мировоззренческие структуры индивидуального сознания, происходит либо непосредственно, через освоение философии, либо опосредованно, через те сферы общественного сознания, которые в процессе "обмирщения" философии переструктурируются, изменяют свое мировоззренческое звучание (религия, мораль, искусство, политическая и правовые формы общественного сознания). В частности, христианство в период своего возникновения испытало значительное влияние, как стоицизма, так и неоплатонизма.

Ф.Ницше, заявивший еще в конце XIX века о том, что "Бог умер", фактически признал, что христианское духовное пространство, бывшее в течение многих столетий несущей конструкцией всей западной цивилизации, близко к исчерпанию. Человечество оказалось перед необходимостью утверждения принципиально нового, общецивилизационного духовного пространства, которое объединит в себе все лучшие духовные достижения предшествующих эпох и откроет новые возможности для того, чтобы современная философия была представлена в качестве не только эзотерической, но и экзотерической формы знания.

Э.Фромм - в своей книге "Революция надежд" - обращает внимание на тот факт, что на Западе многие идеологии и понятия потеряли свою привлекательность, а традиционные клише "правые" и "левые", "коммунизм" и "капитализм" - утратили свое значение, что люди ищут новую ориентацию, новую философию, при которой в центре внимания находилась бы жизнь физическая и духовная. "В США и во всем остальном мире четко просматривается растущая поляризация: на одном полюсе находятся те, кто чувствует неодолимую симпатию к власти, к "закону и порядку", к бюрократическим методам и, в конечном счете, к разрушению жизненных ценностей; на другом - те, кто испытывает страстную тягу к жизни, кто пытается заменить новыми воззрениями устаревшие планы и клише. В последнем 
случае речь идет о людях, которые требуют основополагающих преобразований наших взглядов на жизнь, глубоких изменений в нашей экономической и общественной деятельности. Bcex их объединяет желание сделать активным каждого человека, возродить контроль людьми всей общественной системы и гуманизировать технику. Все это должно быть сделано во имя жизни на Земле, поскольку угроза существования самой жизни реальна сегодня не только для отдельных классов или наций, но и для всех нас" (14. - С.13-14).

3.2. Логика развития философской культуры такова, что на основе увеличения важности личностного фактора для общественного развития в целом, имеет место тенденция все большего увеличения в процессе очередного цикла "обмирщения" философии доли ее непосредственного вхождения в индивидуальное сознание. Но сама возможность развития философской мысли превращается в действительность только в условиях, когда обществу это нужно и когда ему удается создать условия для очередного, более массового вхождения индивидов в культуру, в том числе и в культуру философскую. В свою очередь такие возможности открываются на определенных этапах развития самого общества, обусловленных и его собственной логикой развития, и его особым взаимодействием как с природнокосмической реальностью, так и с самими индивидами.

Индивид в качестве духовного существа в первую очередь продукт и заявка космическо-природной реальности и в этом плане он более самоценен, чем общество. Но поскольку общество порождено космосом как та особая среда, в которой человек только и может становиться человеком, и поскольку как относительно самостоятельная космическая система общество стремится к саморазвитию и самосохранению, постольку в определенные моменты своего существования оно использует индивидов не в качестве цели, а в качестве средства (см. 4). В таких ситуациях индивиды, входящие в измененные состояния сознания, рассматриваются обществом как нарушающие его стабильность отступники и караются. Но в критические моменты, когда общество, не имея возможности двигаться по ранее установленной колее, вступает в ситуацию самораспада, именно 
индивиды, накопившие опыт неординарного видения, опыт неординарных решений оказываются для него не только более предпочтительными, но и как бы палочкой-выручалочкой.

Именно в такие периоды общественной жизни открываются перспективы для осознания и поддержки приоритета философской культуры. Процесс проходит достаточно безболезненно только в том случае, если к этому времени властвующая элита осознала в качестве приоритетной ориентацию не на собственные узкокорыстные эгоистические интересы, а на общечеловеческие интересы, на интересы личности. Только в этих условиях она заинтересована по-настоящему в поддержке философской культуры, ибо нуждается в постижении логики самой жизни, способна понять и принять тот факт, что все изменения в общественной жизни начинаются с изменений в душах отдельных индивидов. К.Маркс, размышляя над истоками протестантской реформации и места в ней Лютера, как-то заметил, что "революция началась в мозгу монаха". Б.Пастернак в стиле изящной философствующей поэзии так же касается этой проблемы: "Не потрясения и перевороты для новой жизни открывают путь. А откровенья, думы и щедроты души воспламененной чьей-нибудь".

Если еще более приземлить рассмотрение логики общественного развития, то можно предположить, что появление так называемого среднего класса, подключенного к материальным достижениям западной цивилизации, открывает возможности на следующем, очередном этапе развития мировой цивилизации появления класса (или страны) "срединной культуры", для которого в качестве высшей ценности будет выступать уже не материальное, а духовное богатство. Можно также предположить, что наиболее благоприятные обстоятельства для этого в недалеком будущем обнаружатся, в первую очередь, именно на пространстве восточнославянской цивилизации. Хотя непосредственно на сегодняшний день, как отметил еще Э.Фромм, нигде так не идеализируют достижения материального благополучия Запада, как в этом регионе. В качестве промежуточного звена к решению этой проблемы может, с нашей точки зрения, выступить факт оформления свободной интеллигентности в особую 
социальную прослойку, позволяющий ей выступить в качестве субъекта новой духовной реальности.

В деле решения индивидами проблем природно-космического и общественного развития многое зависит и от уровня их личностного развития. Соответственно, можно было бы выделить следующие уровни: агрегатной личности, плеядной и монадной. Для агрегатной личности философская культура избыточна, ибо она ориентирована на решение проблем исключительно индивидного существования. Плеядная личность предполагает постоянное утверждение себя в этом мире, нахождения "себя в других", а "других в себе", что побуждает к философской рефлексии и развивает потребность в философской культуpe. На уровне монадной личности философская культура выступает необходимым и неотъемлемым компонентом, ибо в ней сосредотачивается все лучшее из прошлого и будущего развития культуры. Философия соучастия должна учитывать как разную степень подготовленности индивидов к освоению философии, так и замечание Фихте о том, что каждый готов в первую очередь к освоению той философии, к которой он подготовлен самой жизнью.

3.3. Мы исходим из предпосылки, что философия соучастия как синтетическая характеристика философской культуры, адресованной конкретному индивиду, одновременно и существовала всегда, и ей еще только предстоит утвердить себя в этом мире. Раньше, в критические и поворотные моменты мировой истории, к философии соучастия подключались отдельные выдающиеся индивиды с тем, чтобы через вхождение в измененное состояние сознания, через обретение на этом пути высшего уровня структурирования духовности создать предпосылки для осмысления и последующей реализации всем мировым сообществом новых путей его развития.

Один из моментов подобного движения образно зафиксирован в письме-отчете юноши Маркса к отцу от 10.XI.1837 г. "Бывают в жизни моменты, которые являются как вехами, завершающими истекший период времени, но одновременно с определенностью указывают на новое направление жизни. В подобные переходные моменты мы чувствуем себя вынужденными 
обозреть орлиным взором мысли прошедшее и настоящее, чтобы таким образом осознать свое действительное положение. Да и сама всемирная история любит устремлять свой взор в прошлое, она оглядывается на себя, а это часто придает ей видимость попятного движения и застоя; между тем она, словно откинувшись в кресле, призадумалась только, желая понять себя, духовно проникнуть в свое собственное деяние - деяние духа" (9. - С.8). Размышляя над своим действительным положением, над сложностью тех проблем, с которыми ему предстоит разобраться, Маркс вынужден был признаться и себе и отцу: "Снова для меня стало ясно, что без философии мне не пробиться вперед" (9. - С.13).

Определенное уточнение в выделении специфики философии соучастия и подчеркивании ее важности для "кризисных эпох", можно, с нашей точки зрения, увидеть в разделении М.Бубером всех мыслителей на "проблематичных" и "непроблематичных". По его мнению, "Аристотель, Аквинат, Гегель, захвачены проблемами бытия, но они "непроблематичны" по характеру. Их не мучает вопрос: "быть или не быть?" Как характер, как личность они прочно укорены в бытии, "обустроены". Другое дело - Августин, Паскаль, Кьеркегор. Их мысль исповедальна, автобиографична" (см.2. - С.6). Разумеется, и у "непроблематичных" мыслителей бывали определенные моменты в их индивидуальном развитии ("точки бифуркации"), когда еще только решался вопрос о том, удастся или не удастся им "укорениться в бытии" и именно философия, выступающая в качестве философии соучастия, позволяла им положительно решать для себя данную проблему. Современность и предполагает, и открывает новые возможности для того, чтобы философия соучастия сумела непосредственно перейти от уровня эзотерических учений на уровень формы общественного сознания и стала доступна, превратилась в явление духовной жизни многих рядовых индивидов.

Таково прогнозируемое будущее (один из возможных вариантов), но его реализация предполагает, что данная тенденция будет схватываться и осознаваться как потребность, как пространство самореализации все большим и большим количеством 
индивидов. Будущее можно приближать, его нужно утверждать различными способами, в том числе и посредством созидания философии соучастия как того духовного пространства, в котором наш современник может жить более полноценной духовной жизнью уже сегодня.

\section{4. Практический аспект философии соучастия}

4.1. Познавательные проблемы не есть чисто теоретические, а скорее практически-теоретические, потому грань между теоретическим и практическим аспектами философии в некоторых отношениях условна и подвижна. Теоретический аспект философии ориентирован, главным образом, на восхождение от единичного через особенное к всеобщему. Практический аспект философии открывает возможность применить соответствующим образом выявленные и развитые всеобщие принципы к ситуациям конкретным и уникальным. Если человек одновременно и продукт исторического процесса и его творец, то философия призвана выступать в качестве средства осознания современных наличных объективных и субъективных предпосылок его бытия. "Философия, - как заметил Гегель, - должна, прежде всего, доказать нашему обыденному сознанию, что существует потребность в собственно философском способе познания или даже пробудить такую потребность" (3. - С.88).

Теоретический аспект философии соучастия предполагает выявление конкретным философствующим индивидом внешних и внутренних предпосылок для развития культуры его мировоззренческой рефлексии. Практический аспект философии соучастия ориентирован на решение задачи нахождения этим индивидом своих уникальных и неповторимых смыслов и на реализацию их в своей жизнедеятельности. Поскольку мы находимся на уровне общей постановки проблемы, постольку разделение на практический и теоретический аспекты философии в нашем изложении не будет выдерживаться достаточно последовательно.

4.2. Практический аспект философии соучастия представляется нам чрезвычайно многоплановым. Сердцевину его состав- 
ляет проблематика духовности, а также смысложизненная проблематика. "Спецификою людського існування, - отмечает Г.И.Горак, - є його духовність" (4. - С.123).

Духовность может выступать в своих исходных формах проявления как обслуживающее средство (деятельности, общения, игры), а в зрелых формах как самодовлеющая и самостоятельная целостность и ценность. Можно проводить известное различение между духовностью формирующейся условиями самой повседневно-практической жизни, религиозной духовностью и духовностью, взращенной и подпитываемой философской культурой. Н.Бердяев рассматривает духовность как "бытие, нацеленное или направленное духом". Она предполагает стремление быть чуть выше того, что ты из себя сейчас представляешь.

Проблематика духовности составляет одну из величайших загадок человеческого в человеке. Не просто объяснить тот факт, что в условиях фашистских концлагерей, когда громадное большинство узников оказывалось в ситуации близкой к животному существованию, часть из них (хотя и очень незначительная), не обладавшая к тому же лучшими физическими данными, обнаружила своеобразное "упрямство духа" (В.Франкл). А разве меньшее величие и стойкость духа продемонстрировали лучшие советские разведчики в годы Отечественной войны, своеобразным нерукотворным памятником которым и явился фильм "Семнадцать мгновений весны"? Может, действительно, как в онтогенезе, так и филогенезе человек становится Человеком в той мере, в какой духовное начало обнаруживает в нем зрелость и известную самодостаточность существования!?

Решение проблемы обнаружения духовных основ человеческого общежития как для себя лично, так и для других можно рассматривать в наше время как условие становления и развития духовной жизни индивида. Данная проблематика актуальна не только для постсоветского пространства, но и для Запада. Как заметил Э.Фромм, если 3.Фрейд в свое время сказал, что человечеству было известно, что оно обладает духом, а ему пришлось показать человечеству, что у него есть влечения, то сегодня важно придать человеку мужество духовно жить, чтобы напомнить ему, что у него есть дух, что он духовное существо. 
Обращаясь к смысложизненной проблематике, можно предложить в данном случае один из ее аспектов, отправляясь от очень метко и образно схваченной В.Распутиным проблемы противоречивости индивидуального бытия каждого из нас. "Человек сам по себе глубок, прежде всего, собственной жизнью. Он иногда даже не догадывается о своей глубине и не пользуется ее содержимым. Скребет, что называется, поверху, не заглядывая внутрь. Обидно, что часто, не заглянув, так и уходит из жизни, себя не познав, не познав своих возможностей" (см. 5. - С.92). В.Франкл также замечает, что люди, не имеющие цели в жизни, несутся по ней с такой быстротой, что не замечают ее бесцельности. Это проблема, которую не может так просто обойти любой нормальный индивид. Хотя может быть им поставлен и такой вопрос: "Какая мне разница сумею ли я глубоко себя понять и реализовать в этой жизни или нет. Ведь главное быть счастливым?!" Однако при таком подходе индивид, в лучшем случае, столкнется с иллюзией счастья, как бы с миражом, который быстро рассеивается, обнаруживая при этом пустоту всей предшествующей жизни. Возможность подобного трагического завершения индивидуальной жизни глубоко раскрыта в повести Л.Н.Толстого "Смерть Ивана Ильича". С позиций глубинного предназначения истинно человеческого существования эту проблему осознают как смысложизненную проблему. "Останется ли что-нибудь после меня, тогда когда меня уже не будет?", - задает себе вопрос Л.Н.Толстой. Размышляя в "Исповеди" над возможностью придания жизни такого смысла, который не уничтожается смертью, он делает любопытный вывод о том, что “для того, чтобы человек мог жить, ему нужно или не видеть бесконечного, или иметь такое объяснение смысла жизни, при котором конечное приравнивалось бы бесконечному" (12. C.133).

В.Франкл в своей известной работе - "Человек в поисках смысла", - обстоятельно анализирует смысложизненную проблематику. Во-первых, он показывает, что смысл жизни человеку придается либо ценностями деятельности (творчества), либо ценностями переживания (любви), либо ценностями отношения. Во-вторых, проводит различие между смыслами, которые чело- 
век проживает, смыслами, которые он находит, и сверхсмыслами. В третьих, обращает внимание на то, что выход на осмысление сверхсмыслов открывает перед человеком возможности реализации его мессианского предназначения.

4.3. Размышляя над проблематикой философии соучастия, я обнаружил, что многие ее не понимают (не чувствуют), а потому не принимают. Факт непонимания общих контуров рассмотрения философии в качестве философии соучастия может быть объяснен как известной неготовностью читателя к освоению материала, так и неготовностью самого автора к подаче его в достаточно разработанном виде, в понятной и усвояемой форме.

4.3.1. "Вина" читателя может быть связана и с тем, что многие индивиды не готовы к рефлексии над мировоззренческими проблемами. Поэтому для них оказывается неинтересен процесс, открывающий пути к творческому освоению пространства собственного саморазвития и самовыражения.

С.А.Рубинштейн выделяет у человека как субъекта жизни два основных его способа существования и два отношения к жизни, один из которых закрывает для него саму возможность овладения философской культурой.

Первый способ существования являет собой жизнь в сложившихся условиях повседневного быта, не выходящую за пределы непосредственнных жизненных связей. Здесь все интересы и проблемы человека существуют внутри непосредственной жизни и всякое его отношение - это отношение к отдельным частным явлениям, а не к жизни в целом. Индивид не может еще выключиться из непосредственного переживания жизни, не может занять мысленную позицию вне ее, для рефлексии над ней, ибо такая жизнь почти как природный процесс. Социальная регуляция в виде норм нравственности в данном случае определяет саморегуляцию поведения индивида; здесь нравственность существует как невинность, как неведение зла, как естественное природное состояние человека, состояние нравов, его бытия.

Второй способ существования связан с появлением рефлексии. Человек становится способным занимать позицию как бы вне процесса жизни, смотреть на нее как бы со стороны. Сознание выступает здесь как прорыв, как выход из полной по- 
глощенности непосредственным процессом жизни для выработки соответствующего отношения к ней, занятия позиции над ней, вне ее для суждения о ней с целью построения нравственной человеческой жизни на сознательной основе. С появлением рефлексии начинается философское осмысление жизни: отсюда, с этого момента возникает проблема "ближнего" и "дальнего", проблема соотношения, взаимосвязи, непосредственного, неосознанного отношения человека к жизни и опосредованного через "дальнее", осознанного отношения (см. 5. - С.12-13).

4.3.2. "Вина" автора, связанная со сложностью и непонятностью предложенной им проблематики, может иметь свое объяснение, в частности, в том, что процесс исследовательской работы включает как этап собственно исследования, так и этап изложения полученных результатов. Сам автор вынужден проходить ряд последовательных этапов - "в себе", "для себя" и "для других" - в осмыслении и разработки проблемы и только на последнем этапе готов выразить свою точку зрения с учетом и потребности, и настроенности других. Поэтому попытаемся еще раз кратко зафиксировать суть предложенной к рассмотрению в данной статье проблемы.

1) Трудности выхода из нравственного кризиса в нашем обществе в значительной мере связаны с отсутствием у громадного большинства духовно ориентированных индивидов культуры мировоззренческой рефлексии, достаточной для того, чтобы выйти на осознание себя в качестве "современного человека" (К.Юнг). Последнее обстоятельство делает рассматриваемую проблему общественно значимой и актуальной.

2) Как и многие другие, я также ощущаю недостаток необходимой культуры мировоззренческой рефлексии. Но поскольку философия является сферой моей профессиональной деятельности, постольку я испытываю потребность в рефлексии над причинами и природой отчуждения от своей собственной профессиональной деятельности.

3) В своих попытках перейти к ситуации снятия отчуждения ставлю и рассматриваю в предложенной статье три вопроса. Вопервых, возможно ли теоретическое осмысление на уровне философской рефлексии тех внешних и внутренних условий, от- 
сутствие которых препятствует решению этой задачи мною, как и многими другими индивидами (возможно ли выявление всеобщих оснований относительно внешних и внутренних условий)? Во-вторых, возможно ли, опираясь на полученную информацию, мне лично более эффективно включиться в решение проблемы выработки и использования культуры мировоззренческой рефлексии? В третьих, возможно ли тот срез философской культуры (может быть это просто особый способ структурирования и организации наличного философского материала), который призван непосредственно "работать" на постановку и решение данной проблемы, обозначить как "философия соучастия"?

Если действительно, как нас учил Гераклит, "многознание уму не научает", то, возможна ли такая подача философского материала, такое знание, овладение которым учило бы и искусству мыслить, и искусству жить? Ведь всякое иное знание не только излишне, но просто вредно (особенно в условиях информационной перенасыщенности). Возможна ли философия близкая к здравому смыслу, наподобие понимающей социологии Шюца, призванная дать надежду обыкновенному порядочному человеку в том, что он способен, что он может помочь себе сам в деле "собирания себя" - увидеть и поддержать то духовное, что наличествует как в нем самом, так и в окружающих его людях?

Подводя итог предложенным здесь наброскам к размышлению над крайне актуальной проблемой, сделаем некоторые предварительные выводы о возможности философии в качестве философии соучастия для "рядовых от философии". Возможность включения в процесс освоения философии соучастия предполагает уважсительное отношение как к метафизике бытия, так и к философской культуре, ощущение "неукорененности в бытии" как в личностном, так и в общественном плане и желание от него избавиться. Подлинно конструктивное решение рассмотренных выше проблем невозможно в одиночку, оно предполагает наличие творческого коллектива единомышленников, в котором каждый решает эту задачу и для себя и для других. 


\section{ЛИТЕРАТУРА}

1. Библер В.С. Что есть философия? - Вопросы философии, 1995, № 1. - C.159-183.

2. Бубер М. Два образа веры. - М.: Республика. 1995. - 464 с.

3. Гегель Г. Феноменология духа. - Соч., т.IV., М., 1959. - 440 с.

4. Горак Г.І. Філософія. - Київ: Вілбор.1997. - 272 с.

5. Гримак П.П. Общение с собой: начала психологии активности. -

М.: Политиздат, 1991. - 320 с.

6. Ильенков Э.В. Философия и культура.- М.: Политической литературы. - 1991. $-467 \mathrm{c}$.

7. Мамардашвили М. Необходимость себя. - М.: "Лабиринт", 1996. $432 \mathrm{c}$.

8. Мамардашвили М. Лекции по античной философии. - Путь к очевидности. - М.: Аграф, 1997. - 320 с.

9. Маркс К. Письмо к отцу от 10.XI.1837 г. - Маркс К. и Энгельс Ф. Соч., 2-е изд., т. 40. - С. 8 - 18.

10. Маркс K. Экономическо-философские рукописи 1844 года. Маркс К., Энгельс Ф. Соч. 2-е изд., т.42. - С. 41-174.

11. Налимов В.В. Спонтанность сознания. - М.:Прометей,1989. - 287 с.

12. Толстой Л.Н. Исповедь. - Собрание сочинений в 20-ти томах, т.16., М.: Художественная литература, 1964. - С.94-159.

13. Франкл В. Человек в поисках смысла. - М.: Прогресс, 1990. - 386 с.

14. Фромм Э. "Революция надежды". - Санкт-Петербург: Ювента, 1999. $-245 \mathrm{c}$. 